\title{
The effects of exercise training in patients with peripheral vascular disease - a review
}

\author{
B M Parr (MSc (Med) Exercise Science) ${ }^{1}$ \\ E W Derman (MB ChB, PhD) ${ }^{2}$ \\ ${ }^{1}$ Cape Peninsula University of Technology \\ ${ }^{2}$ University of Cape Town MRC/UCT Research Unit for Exercise Science and Sports Medicine
}

\begin{abstract}
Patients with peripheral vascular disease (PVD) suffer from the symptom of intermittent claudication and are therefore intolerant to walking. Exercise training has been shown to be a beneficial treatment for patients with PVD. Therefore studies have aimed to assess the efficacy of exercise training programmes. This review summarises the data on the efficacy of exercise training programmes in patients with PVD. Recommendations are made for the mode, duration, frequency and intensity of exercise training programmes.
\end{abstract}

A systematic review of Medline, Pubmed and Science Direct was done of studies on exercise training and patients with PVD, particularly those using randomised controlled trials.

Exercise training improves walking tolerance in patients with PVD. The common mode of training in patients with PVD in the past decade has been walking on a treadmill; however recently an upper-limb cycle ergometry programme proved to be as effective as lower-limb cycle ergometry in improving walking tolerance in patients with PVD. As weight-bearing walking programmes are uncomfortable for patients with PVD, this is an important development in exercise prescription for these patients. Most successful exercise programmes have been 3-6 months in duration for a period of 30 minutes to 1 hour, 2-3 times per week. However, 1 study showed that a shorter period (6 weeks) was of sufficient duration to improve functional capacity in patients with PVD. This is helpful for practitioners as exercise programmes of 3 or 6 months can be daunting

\section{CORRESPONDENCE:}

\section{B M Parr}

Department of Sport Management

Faculty of Business

Cape Peninsula University of Technology

PO Box 652

Cape Town

Tel: 021-680 1573

Fax: 021-680 1562

E-mail: parrb@cput.ac.za for a patient to embark on. Finally, patients should exercise to maximal claudication pain in order to elicit the best training response.

\section{Introduction}

Peripheral vascular disease (PVD) is a leading cause of morbidity in the elderly in the United States where there are an estimated 5 million affected individuals. ${ }^{9}$ The prevalence of PVD increases with age and it has been estimated that the biennial incidence rate is 26.6 per 1000 men and 13.3 per 1000 women in the United States. ${ }^{27}$ In the United Kingdom it occurs in approximately 1 in 20 of the population between the ages of 55 and 74 years. ${ }^{16}$

Data from the Framingham Heart Study revealed that risk factors for PVD include age, gender, serum cholesterol, hypertension, cigarette smoking, diabetes and coronary artery disease. Male gender, age and smoking were associated with a 1.5-fold increased risk for PVD; diabetes and stage 2 or greater hypertension conferred a >2-fold increased risk; and coronary heart disease nearly tripled the risk for PVD. ${ }^{32}$ These findings are similar to those reported by Newman et al. ${ }^{33}$ who recognised cigarette smoking as a primary risk factor for PVD.

Twenty-five per cent of patients with PVD deteriorate steadily but only $5 \%$ deteriorate to the point that they require leg amputations. ${ }^{9,13}$ Intermittent claudication is the most common symptom of PVD; it causes severe walking intolerance and therefore impacts on the functional status and quality of life of the patient. ${ }^{4,38}$ Therefore treatment has focused on alleviating the symptom of intermittent claudication and improving walking tolerance.

\section{Measurement of walking tolerance in patients with intermittent claudication}

To prove that exercise training is effective, walking tests are necessary. Set testing protocols on the treadmill are common tools to assess walking tolerance in patients with PVD. A wide variety of treadmill walking tests have been used to quantify improvements in walking distances and functional capacity following training in patients with intermittent claudication (Table I). ${ }^{8,19,28,29,30,41}$ 
Two parameters are usually measured on a treadmill: pain-free walking distance (PFWD) and maximum walking distance (MWD). ${ }^{8,22,23}$

Use of the treadmill as a tool to measure walking distance has been criticised because the tests are not always reproducible. $^{26,34,37}$ There is disagreement about whether a graded test (a test when the speed or gradient increases at set time intervals) is more or less reproducible than a constant load test (one that does not increase in speed or gradient).

It has been suggested that a constant load test is fairly reproducible. ${ }^{3}$ Others have found that both the constant load and the graded exercise test are equally well reproducible. ${ }^{5}$ In contrast Gardner et al. ${ }^{17}$ and Perakyla et al. ${ }^{37}$ found the progressive test to be more reproducible and Gardner et al. ${ }^{17}$ suggested that only 1 progressive test is required to obtain

TABLE I. Review of randomised controlled trials on exercise training and patients with peripheral vascular disease

\begin{tabular}{|c|c|c|c|c|c|c|c|}
\hline $\begin{array}{l}\text { Date and } \\
\text { reference }\end{array}$ & Treatment & No of subjects & Program length & $\begin{array}{l}\text { Exercise } \\
\text { frequency/duration }\end{array}$ & $\begin{array}{l}\text { MWD } \\
\% \text { increase }\end{array}$ & $\begin{array}{l}\text { PFWD } \\
\% \text { increase }\end{array}$ & Protocol \\
\hline $\begin{array}{l}\text { Larsen et al. } \\
1966 \text { (28) }\end{array}$ & $\begin{array}{l}\text { - Walking } \\
\text { - Control }\end{array}$ & $\begin{array}{l}7 \\
7\end{array}$ & 6 months & $\begin{array}{l}\text { Home } 1 \mathrm{hr} 7 \mathrm{x} \text { wk } \\
\text { Placebo }\end{array}$ & $\begin{array}{l}282 \% \\
\text { NS }\end{array}$ & $\begin{array}{l}200 \% \\
\text { NS }\end{array}$ & $4.6 \mathrm{~km} \cdot \mathrm{h}^{-1} @ 8 \%$ \\
\hline $\begin{array}{l}\text { Holm et al. } \\
1973(25)\end{array}$ & $\begin{array}{l}\text { - DLE } \\
\text { - Control }\end{array}$ & $\begin{array}{l}6 \\
6\end{array}$ & 4 months & $\begin{array}{l}\text { Supervised } 30 \text { min } 3 x \text { wk } \\
\text { Placebo }\end{array}$ & $\begin{array}{l}42 \% \\
\text { NS }\end{array}$ & $\begin{array}{l}26 \%{ }^{*} \\
\text { NS }\end{array}$ & \\
\hline \multirow{2}{*}{$\begin{array}{l}\text { Mannarino } \\
\text { et al. } 1989 \\
\text { (30) }\end{array}$} & -Walk/DLE & 8 & 6 months & $\begin{array}{l}\text { Home } 1 \mathrm{hr} 1 \mathrm{x} \text { wk } \\
\text { Supervised } 1 \mathrm{hr} 2 \mathrm{x} \text { wk }\end{array}$ & $67 \%$ & $87 \%$ & $\begin{array}{l}3.2 \mathrm{~km} \cdot \mathrm{h}^{-1} @ 12 \% \\
\text { grade }\end{array}$ \\
\hline & - Placebo & 8 & & Placebo & NS & NS & \\
\hline $\begin{array}{l}\text { Hiatt et al. } \\
1990 \text { (22) }\end{array}$ & $\begin{array}{l}\text { - Treadmill } \\
\text { - Control }\end{array}$ & $\begin{array}{l}10 \\
9\end{array}$ & $\begin{array}{l}12 \text { wks } \\
\text { No treatment }\end{array}$ & Supervised $1 \mathrm{hr}$ & $\begin{array}{l}123 \% \\
\text { NS }\end{array}$ & $\begin{array}{l}165 \% \\
\text { NS }\end{array}$ & $\begin{array}{l}3.2 \mathrm{~km} \cdot \mathrm{h}^{-1} \text { at } 0 \% \\
\text { and } \uparrow 3.5 \% \\
\text { per } 3 \mathrm{~min}\end{array}$ \\
\hline $\begin{array}{l}\text { Lundgren et al. } \\
1989 \text { (29) }\end{array}$ & $\begin{array}{l}\cdot \text { Operation } \\
\cdot \text { Op + DLE } \\
\cdot \text { DLE }\end{array}$ & $\begin{array}{l}13 \\
9 \\
11\end{array}$ & 6 months & $\begin{array}{l}\text { Supervised } 30 \mathrm{~min} \\
3 x \text { wk } \\
\text { Supervised } 30 \mathrm{~min} \\
3 x \text { wk }\end{array}$ & $\begin{array}{l}600 \% \\
900 \% \\
200 \%\end{array}$ & $\begin{array}{l}300 \% \\
400 \% \\
300 \%\end{array}$ & $4 \mathrm{~km} \cdot \mathrm{h}^{-1} @ 0 \%$ \\
\hline $\begin{array}{l}\text { Creasy et al. } \\
1990(8)\end{array}$ & $\begin{array}{l}\cdot \text { PTA } \\
\cdot \text { DLE }\end{array}$ & $\begin{array}{l}20 \\
16 \\
\end{array}$ & 6 months & $\begin{array}{l}\text { PTA } \\
\text { Leg } 30 \text { min } 2 x \text { wk }\end{array}$ & $\begin{array}{l}\text { NS } \\
310 \%\end{array}$ & NS & $3 \mathrm{~km} \cdot \mathrm{h}^{-1} @ 10 \%$ \\
\hline $\begin{array}{l}\text { Parker-Jones et al. } \\
1996 \text { (35) }\end{array}$ & • Stair-master & 6 & 12 wks & $\begin{array}{l}\text { Supervised } 1 \mathrm{hr} \\
2 \mathrm{xwk}\end{array}$ & $\begin{array}{l}\text { NS } \\
\uparrow 171.7 \mathrm{sec}\end{array}$ & $\begin{array}{l}\uparrow 35.5 \mathrm{~s} \\
\uparrow 117.7 \mathrm{sec}\end{array}$ & $\begin{array}{l}3.2 \mathrm{~km} \cdot \mathrm{h}^{-1} \text { at } 0 \% \\
\text { and } \uparrow 3.5 \% \text { per } \\
3 \mathrm{~min}\end{array}$ \\
\hline $\begin{array}{l}\text { Hiatt et al. } \\
1996(23)\end{array}$ & $\begin{array}{l}\text { - Walking } \\
\text { treadmill } \\
\text { - Strength } \\
\text { training } \\
\text { - Control }\end{array}$ & $\begin{array}{l}10 \\
8 \\
8\end{array}$ & 12 wks & $\begin{array}{l}\text { Supervised } 1 \text { hr } 3 x \text { wk } \\
\text { Supervised } 1 \text { hr } 3 x \text { wk }\end{array}$ & $\begin{array}{l}43 \% * \\
\text { NS } \\
\text { NS }\end{array}$ & $\begin{array}{l}61.6 \%{ }^{*} \\
\text { NS } \\
\text { NS }\end{array}$ & $\begin{array}{l}3.2 \mathrm{~km} \cdot \mathrm{h}^{-1} \text { at } 0 \% \\
\text { and } \uparrow 3.5 \% \text { per } \\
3 \mathrm{~min}\end{array}$ \\
\hline $\begin{array}{l}\text { Patterson et al. } \\
1997 \text { (36) }\end{array}$ & $\begin{array}{l}\text { - Supervised } \\
\text { exercise } \\
\text { - Home } \\
\text { exercise }\end{array}$ & $\begin{array}{l}23 \\
23\end{array}$ & 12 wks & $\begin{array}{l}1 \mathrm{x} \text { wk lectures }+ \text { exercise } \\
1 \mathrm{x} \text { wk lectures }+ \text { exercise } \\
\text { instruction }\end{array}$ & $\begin{array}{l}33.9 \% \\
\text { NS }\end{array}$ & $\begin{array}{l}54.5 \% \\
\text { NS }\end{array}$ & \\
\hline \multirow[t]{2}{*}{$\begin{array}{l}\text { Walker et al. } \\
2001 \text { (41) }\end{array}$} & $\begin{array}{l}\text { - Arm cranking } \\
\text { - Cycling }\end{array}$ & $\begin{array}{l}26 \\
26\end{array}$ & $6 \mathrm{wks}$ & $\begin{array}{l}\text { Supervised } 40 \mathrm{~min} \\
\text { 2x per wk } \\
\text { Supervised } 40 \mathrm{~min} \\
\text { 2x per wk }\end{array}$ & $\begin{array}{l}51 \% \\
57 \%\end{array}$ & $\begin{array}{l}29 \% \\
31 \%\end{array}$ & Shuttle test \\
\hline & - Control & 15 & & & NS & NS & \\
\hline $\begin{array}{l}\text { Gardner et al. } \\
2001 \text { (19) }\end{array}$ & $\begin{array}{l}\text { - Walking } \\
\text { - Control }\end{array}$ & $\begin{array}{l}28 \\
24\end{array}$ & 6 months & $\begin{array}{l}\text { Supervised } \\
3 x \text { per wk }\end{array}$ & $\begin{array}{l}77 \% \\
12 \% \\
\end{array}$ & $\begin{array}{l}134 \% \\
25 \%\end{array}$ & $\begin{array}{l}3.2 \mathrm{~km} \cdot \mathrm{h}^{-1} \text { at } 0 \% \\
\text { and } \uparrow 2 \% \text { per } \\
2 \mathrm{~min}\end{array}$ \\
\hline $\begin{array}{l}\text { Zwierska et al. } \\
2005 \text { (44) }\end{array}$ & $\begin{array}{l}\text { - Arm cranking } \\
\text { - Cycling } \\
\text { - Control }\end{array}$ & $\begin{array}{l}34 \\
37 \\
15\end{array}$ & 24 wks & $\begin{array}{l}\text { Supervised } 40 \mathrm{~min} \\
2 x \text { per wk } \\
\text { Supervised } 40 \mathrm{~min} \\
2 x \text { per wk }\end{array}$ & $\begin{array}{l}47 \% \\
50 \% \\
\text { NS }\end{array}$ & $\begin{array}{l}122 \% \\
93 \% \\
\text { NS }\end{array}$ & Shuttle test \\
\hline
\end{tabular}


reliable measurements of PFWD and MWD while 3 tests are necessary when using constant load treadmill tests.

It has also been questioned whether walking on the treadmill accurately assesses walking distance because it measures an 'artificial' walking distance, i.e. subjects are not walking on land. This was made apparent in a study where $76 \%$ of study patients were found to walk much further on a ward corridor walk test than on the treadmill, even though the treadmill was slower. ${ }^{42}$ Due to this finding, other, less artificial methods of assessing walking capacity have been explored. In a study by Montgomery et al. ${ }^{31} 64$ patients repeated two 6-minute walk tests a week apart. The distances walked during the two 6-minute walk tests were similar, resulting in a high reliability coefficient $(R=0.94)$ and a low coefficient of variation (10\%). Only a small non-significant $3-4 \%$ increase in distance and steps was found on the second test.

More recently a group of researchers have used a shuttle walk test. ${ }^{41}$ Patients walk back and forth between 2 cones placed $10 \mathrm{~m}$ apart. The speed at which the patients walk is controlled by audible tones recorded on a cassette. Patients begin walking on the first tone and aim to reach the second cone by the next tone. The time span between tones is decreased over time thereby increasing the speed. The patient stops walking when he/she cannot keep up with the required speed. The authors found that this test offered the advantage of testing more than 1 patient at a time, and was also reproducible, having less than $10 \%$ variability in PFWD and MWD in patients with claudication.

Future research should use tests that are reproducible. From this review it seems that the 6-minute walk test, the progressive treadmill test and the shuttle test are the preferred tests to use.

\section{Exercise training as a treatment for patients with PVD}

Percutaneous transluminal angioplasty (PTA), as well as vascular bypass grafting are accepted methods of treatment for limb ischaemia. ${ }^{6,8,43}$ Conservative treatment for claudication was advocated as early as 1898 when Wilhelm Erb suggested that muscular exercise increased blood flow to the ischaemic limb. ${ }^{14}$ Despite this recommendation, for many years passive exercise (the limb is moved by the nurse or exercise therapist through its range of motion) was the recognised therapy for these patients. ${ }^{2}$ The importance of dynamic (the patient actively performs the exercise him or herself) exercise training as a therapy for patients with intermittent claudication was rediscovered in the 1950s and 1960s. $3,15,28,40$

Larsen and Lassen $^{28}$ performed the first randomised controlled study comparing an exercise training group of patients with a placebo-controlled group and found that pain-free walking time (PFWT) increased from 1.7 minutes to 3.5 minutes after exercise training for 6 months. The mean maximum walking time (MWT) increased from 2.9 minutes to 8.2 minutes. In the control group no significant change was noted. Since this study a number of randomised controlled trials (Table I) have shown similar results. $^{8,19,22,23,25,29,30,35,36,41,44}$

It is clear from Table I that exercise training improves walking tolerance in patients with PVD. Indeed when comparing the effects of exercise training with PTA, exercise training was more beneficial after a 6-month period. ${ }^{8}$

Only 1 study ${ }^{21}$ has found no value to exercise training. The effects of surgical intervention, supervised physical exercise training and no treatment on walking tolerance was studied in patients with intermittent claudication. This group found that exercise training offered no therapeutic advantage compared with untreated controls. A methodological flaw in this study was that patients, despite being recruited between 1994 and 1997, were trained using methods dating from the 1970s. The exercises consisted of dynamic leg exercises while seated in a chair. In an upright position exercises consisted of marking time, walking, running, dancing and playing ball. The response to exercise training was determined by using a treadmill walking test and measuring maximum walking distance. Furthermore the intervention lasted for 1 year and compliance was not reported for the exercise training group.

However earlier findings by this same group reported that surgical reconstruction (vascular bypass graft) combined with exercise training was more effective in improving MWD and PFWD in patients with intermittent claudication than training alone or surgery alone. ${ }^{29}$ Similarly, in other studies, this group did report improvements in MWD and PFWD in patients with intermittent claudication following exercise training. ${ }^{10,11}$

\section{Mode of training used in patients with PVD}

Early studies used walking as the mode of exercise training in patients with PVD. ${ }^{3,28}$ Later studies included 'dynamic leg exercises'. ${ }^{10-12}$ In a study by Creasy et al. ${ }^{8}$ dynamic leg exercises included 'walking, walking on tip toe, walking and running on the spot, static bicycling, step ups, going up and down on tip toes while on an incline and dribbling with a ball'.

In the early 1990s, treadmills became more commonplace in gymnasia and exercise laboratories and treadmill walking replaced 'dynamic leg exercises'. Studies showed that training on a treadmill produced substantial increases in walking distances. ${ }^{22,23,35,39}$ Treadmill walking was established as the accepted mode of exercise training and few studies explored the effects of alternative modes of training on walking distances in patients with PVD.

Two studies did however examine the effects of stairmaster exercise and lower-body resistance training on walking distances in patients with PVD. ${ }^{24,35}$ Neither mode of training produced improvements in walking tolerance. Therefore the researchers concluded that training effects in patients with PVD were specific to the mode of training used. Therefore it seemed logical that treadmill walking would be the most beneficial form of training for improving walking tolerance in patients with PVD. 
More recently, studies have again ventured to explore the effects of modes of training outside of treadmill walking on MWD and PFWD in patients with intermittent claudication. Polestriding, a stationary form of exercise similar to skiing has proved to be beneficial to patients with intermittent claudication, as has upper-limb cycle ergometry. ${ }^{7,41,44}$ The effect of upperlimb and lower-limb cycle ergometry on walking tolerance in patients with intermittent claudication was assessed in the United Kingdom. ${ }^{41,44}$ Patients were randomised to an upperlimb cycle ergometry group or a lower-limb cycle ergometry group and trained twice a week for 6 weeks. ${ }^{41}$ PFWD and MWD on a graded treadmill exercise test improved similarly in both training groups. The authors suggested that central cardiovascular adaptations contributed to the increased walking tolerance in both groups because the heart rate response to submaximal work loads during the upper and lower-limb assessments was reduced after training. The authors pointed out that exercise training using lower-limb weight-bearing exercise can be most uncomfortable for the patient and that an upper-limb programme (using upper-limb cycle ergometers) which produced similar results would be a welcome relief to patients with intermittent claudication.

However, upper-limb cycle ergometers are not available in most gymnasia. Upper-body strength training apparatus is available in all gymnasiums and the efficacy of upper-body strength training programmes on patients with PVD needs to be assessed.

It seems that over the years, the mode of exercise training in patients with PVD has mirrored the trends of the mode of exercise training prescribed to the general population. Most gymnasium programmes today include a combination of treadmill walking, cycling, strength training (using plateloaded machines) and stretching. It is recommended that future research assess the efficacy of conventional exercise programmes.

\section{Duration, frequency and intensity of exercise train- ing in patients with PVD}

The duration of most training programmes, whether home based or hospital based, is 12 weeks - 6 months (Table I), only 1 study $^{41}$ has had a shorter training period (6 weeks). This study showed that training was effective in this time period. ${ }^{41}$ More studies need to ascertain whether a short-term (6-week) exercise rehabilitation programme is of sufficient duration to affect functional improvements in patients with PVD. It can be daunting for a patient to embark on a 6-month programme; a short-term (6-week) programme may be easier to commit to and if the patient improves functionally, they will feel encouraged which will improve compliance.

Although the American College of Sports Medicine has advocated that 30 minutes of exercise every day is the exercise prescription guideline to obtain the health benefits of exercise, no studies have examined the effects of 30 minutes of exercise every day for patients with PVD. ${ }^{1}$ The frequency of most training programmes in patients with PVD has been 2
- 3 times per week usually for a period of between 30 minutes and 1 hour (Table I). This is the most practical for patients with PVD as most people in this group are elderly and do not want to commit to more than 2 - 3 times a week for exercise training.

The effects of intensity of a training programme was examined in a meta-analysis. Claudication end point used during an exercise training programme was the most important independently related predictor of the positive change in PFWD and MWD in patients with intermittent claudication. ${ }^{18}$ More recently, this same group of researchers assessed the efficacy of a 6-month exercise rehabilitation programme consisting of treadmill walking to near-maximal pain at either $40 \%$ or $80 \%$ of maximal exercise capacity. Those who trained at a lower exercise intensity walked for a longer time period and therefore total work performed in the 2 groups was the same. There was no difference between the 2 groups with respect to MWD and PFWD at the end of the intervention period. Both groups improved equally. ${ }^{20}$ This indicates that patients should walk at a speed to illicit near-maximal pain. If they choose to train at a lower maximal exercise capacity, they should exercise for a longer period so that the total amount of work completed is similar to that of a training programme using a higher intensity.

\section{Supervised hospital-based exercise programmes v. home-based exercise programmes in patients with PVD}

Only a few studies have compared the effects of home v. hospital-based exercise programmes in patients with PVD. ${ }^{36,38,39}$ Regensteiner et al. ${ }^{38}$ showed no improvement in MWD or PFWD in a home-based exercise programme after 12 weeks of training. Patterson et al. ${ }^{36}$ and Savage et al. ${ }^{39}$ found that although the home exercise groups improved, supervised exercise programmes improved PFWD more than home-based exercise programmes over a 3 - 6-month period. Since only a few studies have compared the effects of home v. hospital-based exercise programmes, more research is needed in this area.

\section{Conclusion}

Exercise training improves walking capacity in patients with PVD, indeed 1 study proved that exercise training was more beneficial than angioplasty as a treatment for patients with PVD.

The preferred mode of exercise training in the past decade has been walking on the treadmill. Recent studies have shown that upper-body cycle ergometry proved to be an effective form of treatment for patients with PVD. This is an important development in exercise training for patients with PVD as walking is painful whereas upper-limb cycle ergometry is pain free.

Furthermore, the efficacy of conventional exercise rehabilitation programmes (a combination of treadmill walking, cycling, strength training and stretching) should be assessed 
as conventional exercise is the most commonly prescribed exercise in gymnasia today.

Training programmes of 3 - 6 months duration have proved to be beneficial for patients with PVD. However a shorter (6-week) exercise training programme has proved to be of sufficient duration to affect functional improvements in patients with PVD. It is easier to encourage a patient to join a 6-week exercise programme than a 6-month programme which can be a daunting undertaking for the patient.

It is evident from this review that most studies prescribe half an hour to an hour of exercise 2 - 3 times per week. The ACSM exercise guidelines ${ }^{1}$ are half an hour of exercise daily. However, because of the age of these patients it is difficult to expect them to attend daily exercise classes. They can be encouraged to attend classes 2 or 3 times per week and walk at home on the remaining days.

Both high and low-intensity exercise training programmes have proved to be beneficial for patients with PVD. However, should patients choose to train at a lower maximal exercise capacity, they should exercise for a longer period so that the total amount of work completed is similar to a training programme using a higher intensity.

\section{REFERENCES}

1. American College of Sports Medicine. ACSM Guidelines for Exercise Testing and Prescription. Baltimore: Williams and Wilkins, 1995.

2. Allen EV, Barker NW, Hines EAJ. Peripheral Vascular Diseases. Philadelphia: WB Saunders, 1955.

3. Alpert J, Larsen A, Lassen NA. Exercise and intermittent claudication: blood flow in the calf muscle during walking studied by the Xenon-133 clearance method. Circulation 1969; 39: 353-9.

4. Breek JC, Hamming JF, De Vries J, Ven Berge Henegouwen DP, Van Heck GL. The impact of walking impairment, cardiovascular risk factors, and comorbidity on quality of life in patients with intermittent claudication. J Vasc Surg 2002; 36: 94-9.

5. Cachovan M, Rogatti W, Woltering F, et al. Randomised reliability study evaluating constant-load and graded-exercise treadmill test for intermittent claudication. Angiology 1999; 50: 193-200.

6. Chetter IC, Spark JI, Scott JA, Kester RC. Does angioplasty improve the quality of life for claudicants? A prospective study. Ann Vasc Surg 1999; 13: 93-103.

7. Collins EG, Langbein WE, Orebaugh $C$, et al. Polestriding exercise and vitiamin $\mathrm{E}$ for management of peripheral vascular disease. Med Sci Sports Exer 2003; 35: 384-93.

8. Creasy TA, McMillan PJ, Fletcher EW, Collin J, Morris PJ. Is percutaneous transluminal angioplasty better than exercise for claudication? - preliminary results from a prospective randomised trial. Eur J Vasc Surg 1990; 4: 1359.

9. Criqui $\mathrm{MH}$, Fronek $\mathrm{A}$, Barrett-Conner $\mathrm{B}$. The prevalence of peripheral arterial disease in a defined population. Circulation 1985; 71: 510-5.

10. Dahloff AG, Bjorntorp, Holm J, Schersten T. Metabolic activity of skeletal muscle in patients with peripheral arterial insufficiency. Eur J Clin Invest 1974; 4: 9-15.

11. Dahloff AG, Holm J, Schersetn T, Sivertsson R. Peripheral arterial insufficiency. Scand J Rehabil Med 1976; 8: 19-26.

12. Dahloff AG, Holm J, Schersten T. Exercise training of patients with intermittent claudication. Scand J Rehabil Med 1983; 15: 20-6.

13. Dormandy J, Heeck L, Vig S. The natural history of claudication: risk to life and limb. Semin Vasc Surg 1999; 12: 123-37.

14. Erb W. Intermittierende hinken und andere nervosa storungen in folde van gefaberkrankungen. Klin Wochenschr 1898.

15. Foley WT. Treatment of gangrene of the feet and legs by walking. Circulation 1957; 15: 689.
16. Fowkes FGR, Houseley E, Cawood EH. Edinburgh artery study: Prevalence of asymptomatic and symptomatic peripheral arterial disease in the general population. Int J Epidemiol 1991; 20: 384-92.

17. Gardner AW, Skinner JS, Cantwell BW, Kent Smith L. Progressive v. single stage treadmill tests for evaluation of claudication. Med Sci Sports Exerc 1991; 23: 402-7.

18. Gardner AW, Poelman ET. Exercise rehabilitation programmes for the treatment of claudication pain. JAMA 1995; 274: 975-1000.

19. Gardner AW, Katzel LI, Sorkin JD, et al. Exercise rehabilitation improves functional outcomes and peripheral circulation in patients with intermittent claudication: A randomised controlled trial. J Am Geriatr Soc 2001; 49: 75562.

20. Gardner AW, Montgomery PS, Flinn WR, Katzel LI. The effect of exercise intensity on the response to exercise rehabilitation in patients with intermittent claudication. J Vasc Surg 2005; 42: 702-9

21. Gelin J, Jivegard L, Taft C, et al. Treatment efficacy of intermittent claudication by surgical intervention, supervised physical exercise training compared to no treatment in unselected randomized patients: One year results of functional and physiological improvements. Eur J Vasc Surg 2001; 22: 107-13

22. Hiatt WR, Regensteiner JG, Hargarten ME, Wolfel EE, Brass EP. Benefit of exercise conditioning for patients with peripheral arterial disease. Circulation 1990; 81: 602-9.

23. Hiatt WR, Regensteiner JG, Wolfel EE, Carry MR, Brass EP. Effect of exercise training on skeletal muscle histology and metabolism in peripheral arterial disease. J Appl Physiol 1996; 81: 780-8.

24. Hiatt WR, Wolfel EE, Meier RH, Regensteiner JG. Superiority of treadmil walking exercise $\mathrm{v}$. strength training for patients with peripheral arterial disease. Implications for mechanism of the training response. Circulation 1994; 90: 1866-74.

25. Holm J, Dahloff AG, Bjorntorp P, Schersten T. Enzyme studies in muscles of patients with intermittent claudication. J Clin Lab Invest 1973; 31: 201-5.

26. Johnston KW, Hosang MY, Andrews DF. Reproducibility of noninvasive vascular laboratory measurements of the peripheral circulation. $J$ Vasc Surg 1987; 6: 147-51.

27. Kannel WD. The demographics of claudication and the aging of the American population. Vasc Med 1996; 1: 60-4.

28. Larsen OA, Lassen NA. Effect of daily muscular exercise in patients with intermittent claudication. Lancet 1966; 2: 1093-5.

29. Lundgren F, Dahloff AG, Schersten T, Volkmann R. Intermittent claudication - surgical reconstruction or physical training. Ann Vasc Surg 1989; 209: 346-55.

30. Mannarino E, Pasqualini L, Menna M, Maragoni G, Orlandi U. Effects of physical training on peripheral vascular disease. A controlled study. Angiology 1989; 1: 5-9.

31. Montgomery PS, Gardner AW. The clinical utility of a six minute walk test in peripheral arterial occlusive disease patients. J Am Geriatr Soc 1988; 46: 706-11.

32. Murabito JM, Agostino RB, Silbershaatz H, Wilson PWF. Intermittent claudication: A risk profile from the Framingham Heart Study. Circulation 1997; 96: 44-9.

33. Newman AB, Siscovick D, Manolio TA, et al. Ankle - arm index as a marke of atherosclerosis in the cardiovascular health study. Circulation 1993; 88: 837-45.

34. Ouriel N, McDonnell AE, Metz CE, Zarius CK. A critical evaluation of stress testing in the diagnosis of peripheral vascular disease. Surgery 1982; 91: 686-93

35. Parker Jones P, Skinner JS, Kent Smith L, John FM, Bryant CX. Functional improvements following stairmaster $v$. treadmill exercise training for patients with intermittent claudication. J Cardiopulm Rehabil 1996; 16: 47-55.

36. Patterson RB, Pinto B, Marcus B, Colucci A, Braun T, Roberts M. Value of a supervised exercise program for the therapy of arterial claudication. $J$ Vasc Surg 1997; 25: 312-9.

37. Perakyla T, Tikkanen H, Van Knorring J, Lepantalo M. Poor reproducibility of exercise test in assessment of claudication. Clin Physiol 1998; 18: 18793.

38. Regensteiner JG, Meyer TJ, Krupski WC, Cranford LS, Hiatt WR. Hospital v. home-based exercise rehabilitation for patients with peripheral arterial occlusive disease. Angiology 1997; 48: 291-300.

39. Savage P, Ricci MA, Lynn M, et al. Effects of home versus supervised exercise for patients with intermittent claudication. J Cardiopulm Rehabil 2001; 21: 152-7. 
40. Skinner JS, Strandness DE. Exercise and intermittent claudication. Circulation 1967; 36: 23-9.

41. Walker RD, Nawaz S, Wilkinson CH, Saxton JM, Pockley AG, Wood RFM Influence of upper- and lower-limb exercise training on cardiovascular function and walking distances in patients with intermittent claudication. $J$ Vasc Surg 2000; 31: 662-9.

42. Watson CJE, Phillips D, Hands L, Collin J. Claudication distance is poorly estimated and inappropriately measured. Br J Surg 1997; 84: 1107-9.

43. Whyman MR, Ruckley CV. Should claudicants receive angioplasty or just exercise training? Cardiovasc Surg 1998; 6: 226-31.

44. Zwierska I, Walker RD, Choksky SA, Male JS, Pockley, G Saxton JM Upper- vs lower-limb aerobic exercise rehabilitation in patients with symptomatic peripheral arterial disease: A randomized controlled trial. $J$ Vasc Surg 2005; 42: 1122-30

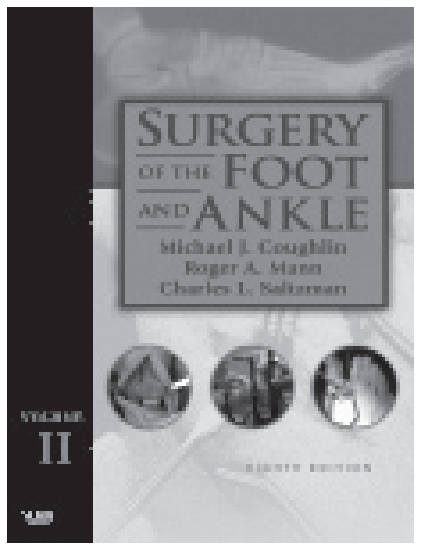

Health \& Medical Publishing Group Surgery of the Foot and Ankle e-dition, 8th edition

Text with Continually Updated Online Reference

By Michael J. Coughlin, MD, Private Practice of Orthopaedic Surgery; Clinical Professor, Department of Orthopaedics and Rehabilitation, Oregon Health Sciences University, Portland, OR; Roger A. Mann, MD, Director of Foot Fellowship Program, Oakland CA; Associate Clinical Professor, Department of Orthopaedic Surgery, University of California at San Francisco School of Medicine, San Francisco, CA; and Charles L. Saltzman, MD, Professor, Departments of Orthopaedic Surgery and Biomedical Engineering, University of Iowa College of Medicine, Iowa City, IA

ISBN 0323040292 • Book/Electronic Media • 1511 Pages • 1580 Illustrations Mosby • Forthcoming Title (December 2006)

\author{
Health \& Medical Publishing Group, \\ Private bag X1, Pinelands, 7430 \\ Tel: 021-6578200 \\ Fax: 021-6834509 \\ e-mail: carmena@hmpg.co.za \\ brents@hmpg.co.za
}

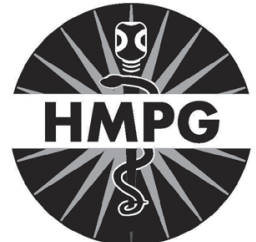

Health \& Medical

Books 